\title{
Chemical composition and antioxidant activity of three species of Cornukaempferia in Thailand
}

\author{
THEERAPHAN CHUMROENPHAT ${ }^{1}$, SURAPON SAENSOUK $^{2, \bullet}$, PIY APORN SAENSOUK $^{3}$ \\ ${ }^{1}$ Laboratory Equipment Center, Division of Research Facilitation and Dissemination, Mahasarakham University, Kantarawichai District, \\ Maha Sarakham, 44150, Thailand, \\ ${ }^{2}$ Plant and Invertebrate Taxonomy and Its Applications Unit Group, WalaiRukhavej Botanical Research Institute, Mahasarakham University, \\ Kantarawichai District, Maha Sarakham, 44150, Thailand •email: surapon.s@msu.ac.th \\ ${ }^{3}$ Plant and Invertebrate Taxonomy and Its Applications Unit Group, Department of Biology, Faculty of Science, Mahasarakham University, \\ Kantarawichai District, Maha Sarakham, 44150, Thailand
}

Manuscript received: 2 July 2021. Revision accepted: 29 August 2021.

\begin{abstract}
Chumroenphat T, Saensouk S, Saensouk P. 2021. Chemical composition and antioxidant activity of three species of Cornukaempferia in Thailand. Biodiversitas 22: 4036-4044. Genus Cornukaempferia (Zingiberaceae) were used as medicinal plants in Thailand. Cornukaempferia has never been reported the chemical compounds and antioxidant activity before. This study was designed to identify the chemical composition and antioxidant activities in root, rhizome, stem, and leaves of Cornukaempferia aurantiflora, $C$. larsenii, and C. longipetiolata. DPPH scavenging activity and Ferric reducing antioxidant power (FRAP) assaysassessed the chemical .composition and antioxidant activity The results showed that total phenolic content (TPC) and total flavonoid content (TFC) found different plant parts obtained in this study were in the order of root $>$ rhizomes $>$ leaves $>$ stems. The $C$. aurantiflora had a high TPC of $416.39 \mathrm{mg} \mathrm{GAE} / \mathrm{g}$ dry weight, while individual phenolics, such as vanillic acid at $256.90 \mathrm{mg} / \mathrm{g}$ dry weight, showed high contents in the leaf part. For $C$. larsenii, TFC and individual flavonoids, such as catechin, have high 62.52 and $56.47 \mathrm{mg} / 100 \mathrm{~g}$ dry weight values in the roots, respectively. The antioxidant activities in different species of different plant parts (DPPH: root $>$ leaves $>$ rhizomes > stems; FRAP: leaves $>$ root $>$ rhizomes $>$ stems). The genus Cornukaempferia is a rich source of bioactive compounds and antioxidant activity. Therefore, the genus Cornukaempferia will be used as medicine and food to produce products with health benefits in the future.
\end{abstract}

Keywords : Antioxidant, flavonoid, phenolic, volatile compounds, Zingiberaceae

\section{INTRODUCTION}

Zingiberaceae is one of the largest family in monocotyledons under the order Zingiberales with about 57 genera of 1,600 species worldwide (KewScience 2021; Saensouk and Saensouk 2021). It is widely distributed in the tropical zone throughout tropical Africa, Asia, and the Americas and the center of diversity of the family is located in Southeast Asia (Saensouk et al. 2016). The family Zingiberaceae is used for food, spices, medicine, dyes, cosmetics, perfume, and ornamental plants, such as Alpinia galanga, Boesenbergia rotunda, Curcuma longa, Zingiber officinale, etc. (Chumroenphat et al. 2019, Saensouk and Saensouk 2021). The small genus Cornukaempferia includes Cornukaempferia aurantiflora, C. chayanii, $C$. kamolwaniae, $C$. larsenii, and $C$. longipetiolata, belongs to the tribe Zingibereae, subfamily Zingiberoideae, family Zingiberaceae (KewScience 2021). Previously, only three species were found in Thailand, namely $C$. aurantiiflora, $C$. larsenii, and $C$. longipetiolata (Saensouk et al. 2016). Later, Yupparach et al. (2019) described two new species from northern Thailand, namely C. chayanii and C. kamolwaniae.

Several plants of Zingiberaceae are generally found in Thailand. These plants have a wide range in all parts for use in Thailand, such as root rhizomes stem leaves and flowers. This family is used as traditional medicine, flavoring agents, spices, natural dyes have both flavorings and medicinal properties (Saensouk et al. 2016; Chumroenphat et al. 2019). Practically all parts of $Z$. officinale, A. galanga, C. longa, K. rutanda. (Maneenoon et al. 2015, Saensouk and Saensouk 2021). In addition, young leaves as vegetables are very important for the daily lives of local people in that area (Saensouk et al. 2016). The rhizome is used as a spice in culinary, beverages, and herbal medicinal practices to treat a wide range of diseases such as rheumatic disorders, cold symptoms, fevers, gastrointestinal complications, motion sickness, bronchitis, diabetes, cancer, etc (Maneenoon et al. 2015; Chumroenphat et al. 2021). Moreover, many species in the family Zingiberaceae have been found to have high contents of bioactive compounds and antioxidant activities (Lu et al. 2013).

The essential oils' constituents and bioactivities of four Zingiberaceae plants have been reported partially, but the anti-inflammatory, antioxidant, and antitumor activities have not been comparatively evaluated. Rheumatoid arthritis is a chronic and disabling inflammatory disease that affects multiple joints (El-sayed et al. 2014). The chemical compounds found in Zingiberaceae were phenolic compounds, flavonoid compounds and volatile compounds have ordor characteristic of Zingiberaceae. The chemical compounds and antioxidants of various Zingiberaceae species have been previously reported. Jena et al. (2017) 
reported that in leaves and rhizomes of $C$. angustifolia chemical components found 32 and 35 compounds, respectively. The predominant of compounds was oxygenated sesquiterpenes. Munda et al. (2018) reported the volatile composition in $K$. galanga rhizomes (Zingiberaceae) was monoterpenes, oxygenated terpenes, and sesquiterpenes as well as non-terpene hydrocarbons, ester, fatty acids, and ketones. Ivanović et al. (2021) reported in the rhizome of $C$. longa (turmeric), Z. officinale (ginger) and A. officinarum Hance (galangal) were founded the main monoterpenes in all the oils studied (1,8-cineol, $\alpha$ terpinyl acetate, limonene, $\alpha$-pinene and $\beta$-pinene) and antioxidant assay (ABTS and FRAP) had highest antioxidant capacity.

There are some reports related to the chemical compounds and antioxidant activity of the Zingiberaceae family plant, but information of Cornukaempferia has never been reported before. Therefore, this study aimed to investigate the analysis of the chemical composition and antioxidant activities of three species of $C$. aurantiflora Mood \& K.Larsen, $C$. larsenii P.Saensouk, and $C$. longipetiolata Mood \& K.Larsen in Thailand. This study will be the first to report and expect to obtain useful information for further development and applications.

\section{MATERIALS AND METHODS}

\section{Plant materials}

The samples were collected from the northeastern part of Thailand in 2015 and identified by Dr. Surapon Saensouk, plant taxonomist and specialist in the genus Cornukaempferia from the Walai Rukhavej Botanical Research Institute, Mahasarakham University, Thailand. Voucher specimens were deposited at the Mahasarakham University Herbarium under collection numbers CT21 CT23 (Table 1). The samples were cleaned and separated $100 \mathrm{~g}$ of each sample into roots, rhizomes, stems, and leaves. After that, the samples were dried using a freeze dryer by Scanvac Cool Safe (model 100-9 Pro, LaboGene ApS, Denmark), and they were then ground and filtrated throughout 60 meshes (Chumroenphat et al. 2019). The samples were stored in desiccators until further analysis.

\section{Plant extraction}

Firstly, $5 \mathrm{~g}$ of each dried sample were added to $50 \mathrm{ml}$ of methanol $(80 \% \mathrm{v} / \mathrm{v})$ and shaken with a shaker incubator for
12 h. After that, the extractions were filtrated with Whatman No.4 filter paper. The extractions were stored at $4{ }^{\circ} \mathrm{C}$ before analysis for total phenolics, flavonoid contents, and antioxidant activity (Kubola et al. 2011).

\section{Procedures \\ Total phenolics and total flavonoid contents}

The total phenolic content (TPC) was determined using a Folin-Ciocalteau assay according to Kaisoon et al. (2011). The absorbance was measured at $725 \mathrm{~nm}$. The extractions were calculated using the external standard gallic acid and were exhibited as mg gallic acid equivalents per $g$ of dry weight. The total flavonoid content (TFC) was described according to Chumroenphat et al. (2021). The absorbance of the mixture was measured at $510 \mathrm{~nm}$. The result was calculated using the external standard rutin, and was presented as mg rutin equivalents per $g$ of dry weight.

\section{Identification of phenolic and flavonoid compounds}

The sample extractions were performed as described by Chumroenphat et al. (2019). Briefly, $1 \mathrm{~g}$ of each sample was extracted with methanol: hydrochloric acid (100:1 v/v). Then, the mixtures were kept at $35^{\circ} \mathrm{C}$ for $12 \mathrm{~h}$ in a shaker incubator .After incubation at $150 \mathrm{rpm}$, the mixtures were filtrated and evaporated in a rotary evaporator at $40^{\circ} \mathrm{C}$ and they were then adjusted to a volume with $5 \mathrm{ml}$ of methanol: water $(80: 50 \mathrm{v} / \mathrm{v})$. The samples were filtrated with a 0.45 $\mu \mathrm{m}$ nylon filter before analysis of phenolic acids and flavonoids using High-Performance Liquid Chromatography (HPLC).

The identification of phenolic acids and flavonoids were determined using HPLC (Shimadzu, Tokyo, Japan) and an InertSustain ${ }^{\circledR} \mathrm{C} 18(4.6 \times 250 \mathrm{~mm}, 5 \mu \mathrm{m})$ column (GL Sciences Inc., Tokyo, Japan). The mobile phase consisted of solvent $\mathrm{A}$ as acetic acid (1\% in water) and solvent $\mathrm{B}$ as acetonitrile at a flow rate of $0.8 \mathrm{ml} \mathrm{min}^{-1}$ and the injection volume was $20 \mu$ l. The gradient elution was described by Ratseewo et al. (2020). The operating conditions were set for the column at a temperature of 38 ${ }^{\circ} \mathrm{C}$ and injection volume of $20 \mathrm{ml}$. The UV-diode array detector for phenolic acids and flavonoids were set at 280 $\mathrm{nm}$ and $370 \mathrm{~nm}$, respectively. Both phenolic acids and flavonoids of the samples were identified by comparing their UV spectra and relative retention times with those of authentic compounds and the external standard method was used for detection of the compounds.

Table 1. Plant materials used in the study

\begin{tabular}{llll}
\hline Collector number & Species & Source & Status \\
\hline CT21 & C. aurantiflora Mood \& K.Larsen & Loei province, Thailand & Cultivated Individual \\
CT22 & C. larsenii P.Saensouk & Loei province, Thailand & Cultivated Individual \\
CT23 & C. longipetiolata Mood \& K.Larsen & Phetchabun Province, Thailand & Cultivated Individual \\
\hline
\end{tabular}




\section{Determination of volatile compounds}

The volatile compounds were undertaken and determined according to Raksakantong et al. (2012). The fractions of the samples were ground and weighed $(0.2 \mathrm{~g})$ in vials and then they were sealed with an aluminum-rubber septum (Supelco, Bellefonte, PA, USA). The headspace sampling technique analyzed the samples. Gas chromatography-mass spectrometry (GC/MS) analysis was carried out using a GC MS series QP2010 of Shimadzu (Tokyo, Japan). Samples were analyzed on a fused silica capillary column Rtx-5MS (5 \%diphenyl and $95 \%$ dimethyl polysiloxane, $30 \mathrm{~m}$ length, $0.25 \mathrm{~mm}$ internal diameter, 0.25 $\mu \mathrm{m}$ film thickness; Restek, Bellefonte, PA, USA). The conditions of analysis were set as follows :constant pressure, $134.2 \mathrm{kPa}$; temperature, $80-250{ }^{\circ} \mathrm{C}$ at $10{ }^{\circ} \mathrm{C} / 1$ min and then held isothermal $(2 \mathrm{~min})$ at $250{ }^{\circ} \mathrm{C}$; ion source temperature, $200{ }^{\circ} \mathrm{C}$; and transfer line temperature, $250{ }^{\circ} \mathrm{C}$. The ionization energy was set at $70 \mathrm{eV}$ and electron ionization mass spectra were acquired over the mass range 40-550 amu. The carrier gas was helium and was split at a ratio, 1:5. The injector temperature was maintained at 250 ${ }^{\circ} \mathrm{C}$. Compounds were identified based on their mass spectra (MS) and computer matching was done with the National Institute of Standards Technology (NIST 11) libraries. The retention indices were calculated using a homologous series of n-alkanes (C7-C30); Sigma-Aldrich, USA.

\section{Determination of antioxidant activity \\ DPPH scavenging activity}

According to Ratseewo et al. (2020), the antioxidant activity was determined and measured in terms of radical scavenging ability using the DPPH method. The extractions were diluted in methanol, and then $0.1 \mathrm{ml}$ of the diluted sample was added to $3 \mathrm{ml}$ of DPPH $(0.1 \mathrm{mM})$ solution, which was freshly dissolved in methanol. After $30 \mathrm{~min}$ in a shaking incubator, the mixtures were placed in the dark at room temperature to protect them from light. The absorbance of the resulting solution was measured at 517 $\mathrm{nm}$ using a spectrophotometer against a control .DPPH scavenging activity was calculated using the following as $\left[\left(\mathrm{A}_{0}-\mathrm{A}_{\mathrm{e}}\right) / \mathrm{A}_{\mathrm{o}}\right] \times 100\left(\mathrm{~A}_{\mathrm{o}}\right.$ : absorbance of the DPPH solution; $A_{e}$ : absorbance of the extract) (Kubola et al. 2011).

\section{Ferric reducing antioxidant power (FRAP)}

The ferric reducing antioxidant power (FRAP) assay measures the ability of reductants (antioxidants to reduce $\left.\mathrm{Fe}^{3+}-\mathrm{Fe}^{2+}\right)$. The Formation of blue-colored $\mathrm{Fe}^{2}{ }_{-}^{+} \mathrm{TPTZ}$ complex ( $\mathrm{Fe} 2+$ tripyridyltriazine) increases the absorbance at $593 \mathrm{~nm}$.The method for the FRAP assay was performed as described with some modifications by Wanyo et al. (2016). Stock solutions were prepared using acetate buffer (300 mM; pH 3.6), TPTZ solution (10 mM in $40 \mathrm{mM} \mathrm{HCl})$ and $\mathrm{FeCl}_{3}{ }^{\circ} 6 \mathrm{H}_{2} \mathrm{O}$ solution $(20 \mathrm{mM})$. The solution was prepared freshly each day and warmed to $37^{\circ} \mathrm{C}$. The FRAP solution $(1.9 \mathrm{ml})$ was allowed to react with the plant extracts $(100 \mu \mathrm{l})$. After $60 \mathrm{~min}$ of reaction, the absorbance was measured using a spectrophotometer at $593 \mathrm{~nm}$. Data were estimated by standard curves prepared with known concentrations of $\mathrm{FeSO}_{4}$ and were expressed as $\mu \mathrm{mol}$ $\mathrm{FeSO}_{4} / \mathrm{g}$.

\section{Data analysis}

All measurements were performed at least three replications and the results were averaged. The analysis was conducted using Statistical Package for the Social Science (SPSS version 14 for Windows). Analysis of variance (ANOVA) with a completely randomized design and Duncan's multiple range test were performed to compare the data $(p<0.05)$.

\section{RESULTS AND DISCUSSION}

\section{Total phenolic and total flavonoid content}

The three species of Cornukaempferia studied were shown to have significant amounts of total phenolics and flavonoids $(p<0.05$ ( The highest total phenolic content (TPC) was observed from the rhizome of $C$. aurantiflora (9.06 $\mathrm{mg} \mathrm{GAE} / \mathrm{g}$ ), while the lowest amount of total phenolic content was found in the stem of $C$. aurantiflora (0.94 mg GAE/g) (Table 2). Ghasemzadeh et al. (2016) reported that Zingiber zerumbet (Zingiberaceae) had high levels of TPC found in the rhizome. However, Ghasemzadeh et al. (2010) found that the TPC was lower in rhizome of Zingiber officinale than in leaves and stem had the lowest. The results of this study indicated that the level of TPC varied greatly among parts of plants and varieties. However, TPC variability may also be related to different environmental and growing conditions (Ezez and Tefera 2021).

Total flavonoid contents (TFC) were observed in all fractions of $C$. aurantiflora, which was significant ( $p<0.05$ (. The highest of TFC was present in the rhizome (35.22 $\mathrm{mg} \mathrm{RE} / 100 \mathrm{~g}$ ), while the lowest was found in the stems of C. aurantiflora (3.00 mg RE/100g) (Table 2). The results suggested that flavonoids are not predominant in these three species. Additionally, C. aurantiflora was the richest source of phenolic compounds and flavonoids, followed by $C$. larsenii and then $C$. longipetiolata. This indicated that the highest TFC levels in all samples were found in the rhizome and the lowest was observed in the stem as presented by Chan et al. (2011) in Alpinia galanga, Curcuma longa, and Etlingera elatior. However, another study by Shahid-Ud-Daula et al. (2019) reported that leaves extracts of E. fimbriobracteata had higher total flavonoid content than the stems and rhizomes. Flavonoids are commonly found secondary metabolites in plants that serve a variety of metabolic functions (Yonekura-Sakakibara et al. 2019). The various flavonoids have a variety of biological activities, including UV protection and phytopathogen defense, signaling during nodulation, male fertility, auxin transport, and flower coloration as a visual signal that attracts pollinators (Falcone Ferreyra et al. 2012). The results indicate that the bioactive compounds depended on the organ of the plant, species, environmental and growing conditions of plant (Ezez and Tefera 2021).

\section{Identification of phenolic acids and flavonoid compounds}

Phenolic acids of three species Cornukaempferia were detected using HPLC. There were 10 standards available, namely gallic acid, protocatechuic acid, $p$-hydroxybenzoic 
acid, chlorogenic acid, vanillic acid, caffeic acid, syringic acid, $p$-coumaric acid, ferulic acid, and sinapic acids (Chumroenphat et al. 2019). All compounds were isolated and identified for the first time from these species. Gallic acid (11.23 mg/g dry weight) and protocatechuic acid ( $25.91 \mathrm{mg} / \mathrm{g}$ dry weight) had the highest content in the leaf and rhizome fractions of $C$. longipetiolata when compared to all other fractions. Vanillic acid showed the highest value $(256.90 \mathrm{mg} / \mathrm{g}$ dry weight) in the leaves of $C$. aurantiflora. Chlorogenic acid was not found in $C$. aurantiflora, while $C$. longipetiolata showed the highest content for chlorogenic acid $(5.53 \mathrm{mg} / \mathrm{g}$ dry weight). Caffeic acid was present in all fractions of $C$. aurantiflora, which appeared at the highest level in the leaf fraction (78.01 $\mathrm{mg} / \mathrm{g}$ dry weight), whereas caffeic acid was disappeared in $C$. longipetiolata. Syringic acid was only present in the $C$. longipetiolata leaf fraction $(17.29 \mathrm{mg} / \mathrm{g}$ dry weight) (Table 3 ). These phenolic acids are found naturally in plants, and they have been reported to be the predominant bioactive in most medicinal plants (Poonthananiwatkul et al. 2015). The finding in this study agreed with previous studies. Elguindy et al. (2016) found that main phenolic compounds identified in cardamom extract (Zingiberaceae) were 4,5-dicapheoylquinic acid, tannic acid, gallic acid and caffeic acid. Akinyemi et al. (2016) reported quantifying different phenolic acids of red ginger (Curcuma longa) and white ginger (Zingiber officinale) in Nigeria reported that found gallic acid and caffeic acid in leaf showed more amount in $C$. longa than $Z$. officinale. Sepahpour et al. (2017) was observed to have the highest amount of chlorogenic acid in the leaves of $Z$. officinale. These finding indicated that concentration and type of phenolic substances varied greatly among varieties however phenolic acids variability may also be related to different environmental conditions grown.

\section{Volatile compounds}

The volatile compounds in the organs of three species of Cornukaempferia were determined using GC/MS and the results are presented in Table 5. There were 18 chemical compositions of volatile compounds that were observed in the rhizome of $C$. larsenii. The result showed that methyl heptadecyl ketone was found at the highest proportion as $59.81 \%$ in $C$. larsenii followed by $C$. larsenii in the root which 16 chemical compounds were found methyl heptadecyl ketone had the highest proportion of $55.49 \%$. There were 15 compounds of chemical composition present in both $C$. aurantiflora (rhizome) and C. longipetiolata (root), which were found at the greatest percentage in 9-Octadecanone $(71.63 \%$ and $70.37 \%$, respectively). The greatest proportion of compounds in the root of $C$. aurantiflora was methyl heptadecyl ketone $(74.74 \%)$ and in C. longipetiolata it was 9-Octadecanone in the rhizome at $70.37 \%$ (Table 5).

The volatile profile of Cornukaempferia exhibited the highest-level significance of terpenoids (methyl heptadecyl ketone, 9-Octadecanone) found in all species (Table 5). Comparative headspace GC/MS investigation of Cornukaempferia organs (root, rhizome, stem, and leaves) has revealed different qualitative and quantitative patterns of their volatile organic compounds. Volatile emissions from both plant parts were dominated by a structurally varied pool of oxygenated compounds, of which ketones and phenolic ethers prevailed in the samples. These data support previous studies, numerous components of Curcuma longa (Zingiberaceae) found in rhizome present study published (Avanço et al. 2018). However, Khaleghi et al. (2012) reported volatile compounds from Etlingera fulgens consisted mainly of non-terpenic compounds and high percentage of $n$-dodecyl acetate in the flower.

\section{Antioxidant activities}

The antioxidant activities in the plant were determined using both DPPH and FRAP assays. The highest values for DPPH inhibition (58.82\%) and total phenolic contents (9.06mg GAE/g) were exhibited in the root of $C$. aurantiflora, when comparing the three fractions (rhizome, stem, and leaves). However, there was no correlation between the FREP assay and total phenolic and flavonoid contents. The result showed that the highest values of FRAP were observed in all leaf fractions of $C$. aurantiflora (46.43 $\left.\mu \mathrm{mol} \mathrm{FeSO}_{4} / \mathrm{g}\right), C$. longipetiolata (46.43 $\mu \mathrm{mol}$ $\left.\mathrm{FeSO}_{4} / \mathrm{g}\right)$ and $C$. larsenii $\left(34.86 \mu \mathrm{mol} \mathrm{FeSO}_{4} / \mathrm{g}\right)$. The lowest FRAP values were displayed for the stems of $C$. aurantiflora and $C$. longipetiolata, whereas for $C$. larsenii it was found in the rhizome. Similar to the DPPH assay, the lowest percentage of inhibition of free radical scavenging was only obtained in the stem of $C$. longipetiolata. (Table 6).

Table 2. Total phenolic and total flavonoid content in three species of Cornukaempferia

\begin{tabular}{lcc}
\hline \multicolumn{1}{c}{ Sample } & $\begin{array}{c}\text { Total phenolic } \\
\text { content } \\
\text { (mg GAE/g) }\end{array}$ & $\begin{array}{c}\text { Total flavonoid } \\
\text { content } \\
\text { (mg RE/g) }\end{array}$ \\
\hline C. aurantiflora Mood \& K.Larsen & \\
Root & $9.06 \pm 0.01^{\mathrm{a}}$ & $24.85 \pm 0.23^{\mathrm{b}}$ \\
Rhizome & $8.05 \pm 0.01^{\mathrm{b}}$ & $35.22 \pm 0.09^{\mathrm{a}}$ \\
Stem & $0.94 \pm 0.04^{\mathrm{k}}$ & $3.00 \pm 0.10^{\mathrm{j}}$ \\
Leaves & $4.15 \pm 0.01^{\mathrm{g}}$ & $12.65 \pm 0.23^{\mathrm{e}}$ \\
C. larsenii P .Saensouk & & \\
Root & $5.20 \pm 0.02^{\mathrm{f}}$ & $10.86 \pm 0.15^{\mathrm{g}}$ \\
Rhizome & $5.98 \pm 0.01^{\mathrm{c}}$ & $16.75 \pm 0.08^{\mathrm{c}}$ \\
Stem & $1.18 \pm 0.03^{\mathrm{j}}$ & $3.61 \pm 0.06^{\mathrm{i}}$ \\
Leaves & $5.61 \pm 0.01^{\mathrm{d}}$ & $12.70 \pm 0.16^{\mathrm{e}}$ \\
C. longipetiolata Mood \& K.Larsen & \\
Root & $5.33 \pm 0.01^{\mathrm{e}}$ & $12.74 \pm 0.21^{\mathrm{e}}$ \\
Rhizome & $5.33 \pm 0.03^{\mathrm{e}}$ & $13.02 \pm 0.08^{\mathrm{d}}$ \\
Stem & $3.24 \pm 0.01^{\mathrm{i}}$ & $5.10 \pm 0.02^{\mathrm{h}}$ \\
Leaves & $3.94 \pm 0.01^{\mathrm{h}}$ & $12.23 \pm 0.06^{\mathrm{f}}$
\end{tabular}

Note: Values are expressed as mean \pm SD of three replications measurement. Numbers on the same column with different superscripts are significantly different at $p<0.05$. 
Table 3. Compositions and contents of phenolic acids in three species of Cornukaempferia studied

\begin{tabular}{|c|c|c|c|c|c|c|c|c|c|c|c|}
\hline \multirow{2}{*}{ Sample } & \multicolumn{10}{|c|}{ Phenolic acids )mg/g( } & \multirow[b]{2}{*}{ Total } \\
\hline & GA & PCCA & $p$-OH & VA & ChA & CFA & SyA & $p$-CA & FA & SNA & \\
\hline \multicolumn{12}{|c|}{ C. aurantiflora Mood \& K.Larsen } \\
\hline Root & $6.25 \pm 0.02^{\mathrm{d}}$ & $6.73 \pm 0.06^{\mathrm{e}}$ & nd & $6.33 \pm 0.07^{\mathrm{f}}$ & nd & $53.07 \pm 0.06^{\mathrm{b}}$ & nd & $18.32 \pm 0.06^{\mathrm{c}}$ & $14.48 \pm 0.31^{\mathrm{a}}$ & $7.10 \pm 0.08^{c}$ & $112.27 \pm 0.07$ \\
\hline Rhizome & $8.17 \pm 0.04^{b}$ & $25.17 \pm 2.22^{\mathrm{a}}$ & nd & $40.81 \pm 0.16^{c}$ & nd & $56.86 \pm 1.44^{\mathrm{b}}$ & nd & $42.35 \pm 0.15^{\mathrm{a}}$ & $14.05 \pm 0.23^{\mathrm{a}}$ & $5.02 \pm 0.01^{\mathrm{d}, \mathrm{e}}$ & $192.43 \pm 0.42$ \\
\hline Stem & $5.47 \pm 0.01^{\mathrm{e}}$ & $7.10 \pm 0.01^{\mathrm{e}}$ & nd & $5.83 \pm 0.55^{\mathrm{f}}$ & nd & $54.51 \pm 0.09^{\mathrm{b}}$ & nd & $6.45 \pm 0.02^{\mathrm{f}}$ & $7.75 \pm 0.07^{\mathrm{d}}$ & $5.31 \pm 0.04^{\mathrm{d}, \mathrm{e}}$ & $92.41 \pm 0.08$ \\
\hline Leaves & $10.83 \pm 0.07^{\mathrm{a}}$ & $4.54 \pm 0.01^{\mathrm{f}}$ & $12.94 \pm 0.10^{c}$ & $256.90 \pm 4.26^{\mathrm{a}}$ & nd & $78.01 \pm 7.09^{\mathrm{a}}$ & nd & $7.35 \pm 0.09^{\mathrm{e}}$ & $11.44 \pm 0.07^{\mathrm{b}}$ & $34.20 \pm 0.19^{\mathrm{b}}$ & $416.39 \pm 1.19$ \\
\hline \multicolumn{12}{|c|}{ C. larsenii P .Saensouk } \\
\hline Root & $6.04 \pm 0.07^{\mathrm{d}, \mathrm{e}}$ & $7.46 \pm 0.18^{\mathrm{e}}$ & nd & $11.99 \pm 0.06^{\mathrm{d}}$ & nd & nd & nd & $4.74 \pm 0.01^{\mathrm{j}}$ & $5.28 \pm 0.07^{\mathrm{e}}$ & $5.54 \pm 0.02^{\mathrm{d}, \mathrm{e}}$ & $41.05 \pm 0.04$ \\
\hline Rhizome & $7.23 \pm 0.39^{\mathrm{c}}$ & $10.66 \pm 0.61^{\mathrm{d}}$ & nd & $45.60 \pm 0.14^{\mathrm{b}}$ & $4.34 \pm 0.06^{\mathrm{d}}$ & nd & nd & $5.47 \pm 0.02^{\mathrm{h}}$ & $4.82 \pm 0.03^{\mathrm{e}}$ & $5.79 \pm 0.11^{\mathrm{d}}$ & $83.91 \pm 0.14$ \\
\hline Stem & $5.84 \pm 0.62^{\mathrm{d}, \mathrm{e}}$ & $7.78 \pm 0.07^{\mathrm{e}}$ & nd & $9.07 \pm 0.05^{\mathrm{e}}$ & $4.74 \pm 0.15^{\mathrm{c}}$ & nd & nd & $4.56 \pm 0.01^{\mathrm{k}}$ & $4.48 \pm 0.09^{\mathrm{e}}$ & $5.18 \pm 0.03^{\mathrm{d}, \mathrm{e}}$ & $41.65 \pm 0.10$ \\
\hline Leaves & $6.26 \pm 0.71^{\mathrm{d}}$ & $8.25 \pm 1.96^{\mathrm{e}}$ & $8.72 \pm 0.03^{\mathrm{d}}$ & $5.78 \pm 0.06^{\mathrm{f}}$ & $4.90 \pm 0.02^{\mathrm{b}}$ & $55.65 \pm 0.61^{\mathrm{b}}$ & nd & $5.20 \pm 0.02^{\mathrm{i}}$ & $9.79 \pm 0.86^{c}$ & $6.69 \pm 0.43^{c}$ & $111.23 \pm 0.47$ \\
\hline \multicolumn{12}{|c|}{ C. longipetiolata Mood \& K.Larsen } \\
\hline Root & nd & $13.60 \pm 0.34^{c}$ & nd & nd & nd & nd & nd & $11.65 \pm 0.01^{\mathrm{d}}$ & $7.58 \pm 0.65^{\mathrm{d}}$ & $5.44 \pm 0.23^{\mathrm{d}, \mathrm{e}}$ & $38.27 \pm 0.12$ \\
\hline Rhizome & $8.61 \pm 0.06^{\mathrm{b}}$ & $25.91 \pm 0.17^{\mathrm{a}}$ & $19.44 \pm 0.06^{\mathrm{a}}$ & nd & nd & nd & nd & $21.78 \pm 0.04^{b}$ & $7.17 \pm 0.18^{\mathrm{d}}$ & $5.49 \pm 0.69^{\mathrm{d}, \mathrm{e}}$ & $88.38 \pm 0.12$ \\
\hline Stem & $7.05 \pm 0.08^{\mathrm{c}}$ & $8.06 \pm 0.03^{\mathrm{e}}$ & nd & $6.22 \pm 0.53^{\mathrm{f}}$ & nd & nd & nd & $5.88 \pm 0.02^{\mathrm{g}}$ & $9.38 \pm 0.73^{c}$ & $4.98 \pm 0.20^{\mathrm{e}}$ & $41.57 \pm 0.16$ \\
\hline Leaves & $11.23 \pm 0.67^{\mathrm{a}}$ & $15.29 \pm 0.45^{\mathrm{b}}$ & $17.94 \pm 1.89^{\mathrm{b}}$ & nd & $5.53 \pm 0.04^{\mathrm{a}}$ & nd & $17.29 \pm 0.30^{\mathrm{a}}$ & $4.79 \pm 0.01^{\mathrm{j}}$ & $14.83 \pm 2.71^{\mathrm{a}}$ & $41.90 \pm 1.09^{\mathrm{a}}$ & $128.80 \pm 0.71$ \\
\hline
\end{tabular}


Table 5. The volatile compounds of three species of Cornukaempferia

\begin{tabular}{|c|c|c|c|c|c|c|c|c|c|c|c|c|c|}
\hline \multirow{3}{*}{ Volatile compounds } & \multirow{3}{*}{$\mathbf{R I}$} & \multicolumn{12}{|c|}{ Area $(\%)$} \\
\hline & & \multicolumn{4}{|c|}{ C. aurantiflora Mood \& K.Larsen } & \multicolumn{4}{|c|}{ C. larsenii P. Saensouk } & \multicolumn{4}{|c|}{ C. longipetiolata Mood \& K.Larsen } \\
\hline & & Root & Rhizome & Stem & Leaves & Root & Rhizome & Stem & Leaves & Root & Rhizome & Stem & Leaves \\
\hline 1R-.alpha.-Pinene & 949 & - & 0.06 & - & - & - & 0.15 & - & - & 0.13 & 0.19 & - & - \\
\hline Camphene & 973 & - & 0.13 & - & - & 0.05 & 0.92 & - & - & 0.46 & 0.24 & - & - \\
\hline -(-)beta.-Pinene & 1017 & - & - & - & - & - & - & - & 18.97 & - & - & - & 44.53 \\
\hline beta.-Myrcene & 1037 & - & - & - & - & - & 0.13 & - & - & 0.07 & 0.07 & - & - \\
\hline beta.-Cymene & 1097 & 0.30 & 0.36 & - & - & 0.05 & 0.15 & - & - & 0.13 & 0.26 & - & - \\
\hline D-Limonene & 1104 & - & 0.09 & - & - & 0.07 & 0.37 & - & - & 0.18 & 0.24 & - & - \\
\hline Eucalyptol & 1109 & 0.43 & 0.95 & - & - & 0.11 & 0.48 & - & - & 1.72 & 2.69 & - & - \\
\hline alpha.-Tolualdehyde & 1133 & - & - & 0.93 & - & - & - & - & - & - & - & - & - \\
\hline gamma.-Terpinene & 1159 & 0.09 & 0.13 & - & - & 0.05 & 0.16 & - & - & 0.07 & 0.15 & - & - \\
\hline Decyl methyl ketone & 1219 & 1.00 & 1.05 & - & - & 0.23 & 0.31 & - & - & 0.89 & 1.36 & - & 30.19 \\
\hline Linalol & 1235 & - & 0.06 & - & - & - & 0.19 & - & - & - & - & - & - \\
\hline$-(+) 2$-Bornanone & 1331 & 0.32 & 0.15 & - & - & 0.69 & 1.22 & - & - & 0.29 & 0.19 & - & - \\
\hline endo-Borneol & 1375 & - & - & - & - & 0.25 & 0.13 & - & - & - & - & - & - \\
\hline L-.alpha.-Terpineol & 1427 & 0.09 & 0.07 & - & - & - & - & - & - & 0.10 & 0.18 & - & - \\
\hline Cycloheptanone, 2-acetonyl- & 1449 & - & - & - & - & 0.16 & - & - & - & - & - & - & - \\
\hline Methyl n-nonyl ketone & 1571 & - & 0.04 & 60.75 & 31.86 & - & - & 49.81 & 30.38 & - & - & 49.81 & 25.28 \\
\hline Methyl heptadecyl ketone & 1668 & 74.74 & 23.02 & - & - & 55.49 & 59.81 & - & - & 61.37 & - & - & - \\
\hline 9-Octadecanone & 1670 & - & 71.63 & 1.09 & - & - & - & - & - & - & 70.37 & - & - \\
\hline Methylundecylcarbinol & 1675 & - & - & - & - & - & - & - & - & 0.45 & - & - & - \\
\hline Alloaromadendrene & 2163 & - & - & - & - & 0.19 & 0.2 & - & - & - & - & - & - \\
\hline trans-9-Octadecene & 2865 & - & 0.34 & - & - & 2.09 & - & - & - & - & 0.26 & - & - \\
\hline Methyl undecyl ketone & 2280 & 21.19 & - & 32.35 & 60.62 & 34.76 & 28.95 & 44.38 & 50.65 & 29.49 & 21.97 & 44.38 & - \\
\hline 1-Butylundecyl acetate & 2532 & - & - & - & - & 0.18 & 0.26 & - & - & - & - & - & - \\
\hline Cycloheptanone, 3-(2-oxopropyl)- & 2601 & - & - & - & - & 0.14 & 0.2 & - & - & - & - & - & - \\
\hline 9-Eicosene, (E)- & 2865 & 0.35 & - & - & - & - & 4.91 & - & - & 0.74 & - & - & - \\
\hline Hexadecane & 2911 & 1.49 & 1.92 & 4.88 & 7.52 & 5.49 & 1.46 & 5.81 & - & 3.91 & 1.83 & 5.81 & - \\
\hline
\end{tabular}

Note: -: not detected; RI: retention index 
Table 4. Composition and content of flavonoid compounds in three species of Cornukaempferia

\begin{tabular}{|c|c|c|c|c|c|}
\hline \multirow[t]{2}{*}{ Samples } & \multicolumn{4}{|c|}{ Flavonoid compounds content (mg/100g dry weight) } & \multirow[t]{2}{*}{ Total } \\
\hline & QC & MC & KF & $\mathrm{CC}$ & \\
\hline \multicolumn{6}{|c|}{ C. aurantiflora Mood \& K.Larsen } \\
\hline Root & $1.69 \pm 0.04^{\mathrm{b}}$ & $2.43 \pm 0.08^{c}$ & $3.26 \pm 0.16^{\mathrm{e}}$ & $19.05 \pm 1.11^{\mathrm{c}}$ & $26.43 \pm 0.35$ \\
\hline Rhizome & $3.25 \pm 0.05^{\mathrm{a}}$ & $3.70 \pm 0.15^{\mathrm{b}}$ & $4.48 \pm 0.06^{\mathrm{cd}}$ & $23.44 \pm 0.61^{\mathrm{b}}$ & $34.87 \pm 0.22$ \\
\hline Stem & $0.73 \pm 0.02^{\mathrm{g}}$ & $1.53 \pm 0.19^{\mathrm{de}}$ & $2.83 \pm 0.01^{\mathrm{e}}$ & $2.41 \pm 0.09^{\mathrm{f}}$ & $7.50 \pm 0.08$ \\
\hline Leaves & $0.76 \pm 0.06^{\mathrm{fg}}$ & $1.43 \pm 0.24^{\mathrm{e}}$ & nd & $12.43 \pm 0.25^{\mathrm{d}}$ & $17.47 \pm 0.14$ \\
\hline \multicolumn{6}{|l|}{ C. larsenii P .Saensouk } \\
\hline Root & $1.23 \pm 0.03^{\mathrm{c}}$ & $1.48 \pm 0.07^{\mathrm{e}}$ & $24.93 \pm 0.06^{\mathrm{b}}$ & $24.88 \pm 5.57^{\mathrm{b}}$ & $62.52 \pm 1.43$ \\
\hline Rhizome & $0.98 \pm 0.02^{\mathrm{de}}$ & $1.53 \pm 0.01^{\mathrm{de}}$ & $41.09 \pm 0.11^{\mathrm{a}}$ & $9.89 \pm 0.16^{\mathrm{de}}$ & $53.49 \pm 0.08$ \\
\hline Stem & nd & $1.53 \pm 0.13^{\mathrm{de}}$ & $3.08 \pm 0.05^{\mathrm{e}}$ & $6.42 \pm 0.10^{\mathrm{e}}$ & $11.03 \pm 0.09$ \\
\hline Leaves & $0.89 \pm 0.11^{\mathrm{ef}}$ & $2.49 \pm 0.14^{c}$ & nd & $56.47 \pm 3.82^{\mathrm{a}}$ & $59.85 \pm 1.36$ \\
\hline \multicolumn{6}{|c|}{ C. longipetiolata Mood \& K.Larsen } \\
\hline Root & $1.62 \pm 0.20^{\mathrm{b}}$ & $1.91 \pm 0.15^{\mathrm{d}}$ & $3.92 \pm 0.19^{\mathrm{d}}$ & $18.81 \pm 2.06^{\mathrm{c}}$ & $26.26 \pm 0.65$ \\
\hline Rhizome & $1.07 \pm 0.18^{\mathrm{d}}$ & $4.38 \pm 0.35^{\mathrm{a}}$ & $4.63 \pm 0.89^{c}$ & $2.02 \pm 0.18^{\mathrm{f}}$ & $12.10 \pm 0.40$ \\
\hline Stem & $0.70 \pm 0.02^{\mathrm{g}}$ & $1.73 \pm 0.13^{\mathrm{de}}$ & $2.88 \pm 0.01^{\mathrm{e}}$ & $25.25 \pm 0.41^{\mathrm{b}}$ & $30.56 \pm 0.14$ \\
\hline Leaves & $0.72 \pm 0.02^{\mathrm{g}}$ & $2.31 \pm 0.49^{c}$ & $3.28 \pm 0.78^{\mathrm{e}}$ & $9.78 \pm 0.11^{\mathrm{de}}$ & $16.09 \pm 0.35$ \\
\hline
\end{tabular}

Note: nd: not detected; QC: quercetin; MC: myricetin; KF: kaempferol; CC: catechin. Values are expressed as mean \pm SD of three replications measurements. Numbers on the same column with different superscripts are significantly different at $p<0.05$.

Table 6. Antioxidant activities of three species of Cornukaempferia

\begin{tabular}{lcl}
\hline \multicolumn{1}{c}{ Samples } & $\begin{array}{l}\text { FRAP } \\
(\mu \text { mol FeSO } / \mathbf{g})\end{array}$ & $\begin{array}{l}\text { DPPH } \\
(\% \text { inhibition })\end{array}$ \\
\hline C. aurantiflora Mood \& K.Larsen & \\
Root & $27.55 \pm 0.18^{\mathrm{d}}$ & $58.82 \pm 0.40^{\mathrm{a}}$ \\
Rhizome & $23.59 \pm 0.13^{\mathrm{g}}$ & $45.76 \pm 2.48^{\mathrm{cd}}$ \\
Stem & $11.25 \pm 0.18^{\mathrm{k}}$ & $20.94 \pm 1.0^{\mathrm{f}}$ \\
Leaves & $46.43 \pm 0.07^{\mathrm{a}}$ & $48.48 \pm 1.35^{\mathrm{bc}}$ \\
C. larsenii P .Saensouk & & \\
Root & $25.42 \pm 0.12^{\mathrm{f}}$ & $51.43 \pm 2.17^{\mathrm{b}}$ \\
Rhizome & $19.78 \pm 0.11^{\mathrm{i}}$ & $51.64 \pm 1.01^{\mathrm{b}}$ \\
Stem & $26.36 \pm 0.07^{\mathrm{e}}$ & $50.54 \pm 2.29^{\mathrm{b}}$ \\
Leaves & $34.86 \pm 0.04^{\mathrm{c}}$ & $40.11 \pm 2.61^{\mathrm{e}}$ \\
C. longipetiolata Mood \& K.Larsen & \\
Root & $20.40 \pm 0.11^{\mathrm{h}}$ & $45.26 \pm 1.14^{\mathrm{cd}}$ \\
Rhizome & $20.58 \pm 0.17^{\mathrm{h}}$ & $42.03 \pm 3.22^{\mathrm{de}}$ \\
Stem & $12.22 \pm 0.19^{\mathrm{j}}$ & $18.62 \pm 2.31^{\mathrm{f}}$ \\
Leaves & $45.33 \pm 0.13^{\mathrm{b}}$ & $47.70 \pm 1.14^{\mathrm{bc}}$ \\
\hline
\end{tabular}

Note: FRAP: Ferric reducing antioxidant activities; DPPH: DPPH scavenging activities. Values are expressed as mean $\pm \mathrm{SD}$ of three replications measurement (n: 3). Means with different letters are significantly different at $p<0.05$ within the same column

The results demonstrated that the antioxidant activities depended on the plant organ .Similarly, many studies have reported that antioxidant activities were found at high values in several organs of plants, for example, the leaves and rhizomes had higher activity than that of the stems found in Zingiber officinale of Malaysia. The FRAP values in rhizome are higher than leaves and stem (Ghasemzadeh, et al. 2010). These results agreed with those of Etlingera fimbriobracteata previously reported by Shahid-Ud-Daula et al. (2019), where leaves have the highest DPPH radical scavenging activity than those of rhizome and stems. Likewise, FRAP measures the ferric reducing ability of the samples. The highest FRAP activity was exhibited by leaves extract, whereas stems were the least active. Thus, statistically, the FRAP activities in different species of different plant parts obtained in this study were in the order of leaves $>$ root $>$ rhizomes $>$ stems.

Both the DPPH and FRAP assays have different mechanisms of action depending on the chemical properties and functionalities of the targeted compounds . For the DPPH assay, the free radical scavenging ability of the samples was measured (Siriamornpun and Kaewseejan 2017), while the FRAP assay determined the reducing potential of a ferrictripyridyltriazine $\left(\mathrm{Fe}_{3}{ }^{+} \mathrm{TPTZ}\right)$ complex by antioxidant reaction to produce a colored ferroustripyridyltriazine. In this study, the antioxidant activities of the DPPH assay was strongly positive correlated with the total phenolic and flavonoids contents . Several researchers have reported the strong positive correlations between the total phenolics and antioxidant activity of plant tissues (Ma et al. 2011, Chumroenphat et al. 2019). In addition, Boulaaba et al. (2019) reported the strong positive correlations between both total phenolic and flavonoid contents and antioxidant activities (DPPH and FRAP assays) in Salsola kali L.

In conclusion, our findings suggest that the chemical compounds and antioxidant activities of three species of genus Cornukaempferia were found ( $C$. aurantiflora, $C$. longipetiolata and $C$. larsenii). The phenolic contents were significant $(\mathrm{p}<0.05)$ in all parts (root, rhizome, stem and leaves) of genus Cornukaempferia. The highest total phenolic content was found in the leaves, while the highest total flavonoids content was observed in the rhizome. The highest contents of three phenolic acids (vanillic, ferulic and sinapic acids) were found in the leaves of the three species of genus Cornukaempferia. The highest values of catechin were found in the rhizome. In contrast, the stem was found to have the lowest total phenolic and flavonoid contents. The rhizome from $C$. aurantiflora had the highest values for antioxidant activity (DPPH, FRAP), while 
methyl heptadecyl ketone was exhibited in all fractions of Cornukaempferia.

This study suggested that the chemical composition and antioxidant activity of three species of Cornukaempferia in Thailand depended on the plant organ and species of plant as well. Differentiation organs from Cornukaempferia in Thailand may be used as potential sources of antioxidant activities and bioactive compounds and provide important evidence supporting the health benefits from Cornukaempferia. The results are expected to be useful information for the potential use of Cornukaempferia as alternative sources of bioactive compounds as functional foods or medicinal plant products.

\section{ACKNOWLEDGEMENTS}

We thank Mahasarakham University, Thailand for financially supported on 2016 and the Laboratory Equipment Center, Mahasarakham University for support, cooperation and scientific aid. We also gratefully thank Dr. Jolyon Dodgson, Myerscough College from the UK for language editing and suggestions to improve the manuscript.

\section{REFERENCES}

Akinyemi AJ, Oboh G, Ademiluyi AO, Boligon AA, Athayde ML. 2016 Effect of two ginger varieties on arginase activity in hypercholesterolemic rats. J Acupunct Meridian Stud 9 (2): 80-87. DOI: 10.1016/j.jams.2015.03.003.

Avanço GB, Ferreira FD, Bomfim NS, Rodriques dos Santos PAdS, Peralta, RM, Brugnari T, Mallann A, Filho BAdA, Graton Mikcha JM, Machinski M, Jr. 2017. Curcuma longa L. essential oil composition, antioxidant effect, and effect on Fusarium verticillioides and fumonisin production. Food Control 73: 806-813. DOI: 10.1016/j.foodcont.2016.09.032.

Boulaaba M, Medini F, Hajlaoui H, Mkadmini K, Falleh H, Ksouri R, Isodade H, Smaouia A, Abdelly C. 2019 .Biological activities and phytochemical analysis of phenolic extracts from Salsola kali L role of endogenous factors in the selection of the best plant extracts .S Afr J Bot. 123: 193-199. DOI: 10.1016/j.sajb.2019.03.003.

Calderon-Montano J, Burgos-Morón E, Pérez-Guerrero C, López-Lázaro M. 2011. A review on the dietary flavonoid kaempferol .Mini-Rev Med Chem 4 (11): 298-344. DOI: 10.2174/138955711795305335.

Chan EW, Ng VP, Tan VV, Low YY. 2011. Antioxidant and antibacterial properties of Alpinia galanga, Curcuma longa, and Etlingera elatior Zingiberaceae Phcog J 3 (2): 54-61. DOI: 10.5530/pj.2011.22.11.

Chumroenphat T, Somboonwatthanakul I, Saensouk S, Siriamornpun S 2019 .The diversity of biologically active compounds in the rhizomes of recently discovered Zingiberaceae plants native to North Eastern Thailand. Phcog J 11 (5): 1014-1022. DOI:10.5530/pj.2019.11.160.

Chumroenphat T, Somboonwatthanakul I, Saensouk S, Siriamornpun S. 2021. Changes in curcuminoids and chemical components of turmeric (Curcuma longa L.) under freeze-drying and low-temperature drying methods. Food Chem 339: 1-9. DOI: 10.1016/j.foodchem.2020.128121.

Elguindy NM, Yacout GA, El Azab EF, Maghraby HK. 2016. Chemoprotective effect of Elettaria cardamomum against chemically induced hepatocellular carcinoma in rats by inhibiting $N F-\kappa B$, oxidative stress, and activity of ornithine decarboxylase. S Afr J Bot 105:251-258. DOI: 10.1016/j.sajb.2016.04.001.

Ezez D, Tefera M. 2021. Effects of solvents on total phenolic content and antioxidant activity of ginger extracts. J Chem 2021: 1-5. DOI: $10.1155 / 2021 / 6635199$.
Falcone Ferreyra ML, Rius S, Casati P. 2012. Flavonoids: biosynthesis, biological functions, and biotechnological applications. Front Plant Sci 3: 1-15. DOI: 10.3389/fpls.2012.00222.

Gairola S, Shariff NM, Bhatt A. 2010. Influence of climate change on production of secondary chemicals in high altitude medicinal plants: issues needs immediate attention. J Med Plants Res 4 (18): 18251829. DOI: $10.5897 / J M P R 10.354$.

Ghafoor K, Juhaimi FA, Özcan MM, Uslu N, Babiker EE, Ahmed IA. 2020. Total phenolics, total carotenoids, individual phenolics and antioxidant activity of ginger (Zingiber officinale) rhizome as affected by drying methods. LWT - Food Sci Technol 126: 1-7. DOI: 10.1016/j.lwt.2020.109354.

Ghasemzadeh A, Jaafar HZ, Rahmat A. 2010. Antioxidant activities, total phenolics and flavonoids content in two varieties of Malaysia young ginger (Zingiber officinale Roscoe). Molecules 15 (6): 4324-4333. DOI: 10.1186/s12906-016-1072-6.

Ghasemzadeh A, Jaafar HZ, Ashkani S, Rahmat A, Juraimi AS, Puteh A, Mohamed MTM. 2016. Variation in secondary metabolite production as well as antioxidant and antibacterial activities of Zingiber zerumbet (L.) at different stages of growth. BMC Compl Med Ther 16 (1): 110. DOI: $10.1186 / \mathrm{s} 12906-016-1072-6$.

Jena S, Ray A, Banerjee A, Sahoo A, Nasim N, Sahoo S, Kar B, Patnaik J, Panda PC. Nayak S. 2017. Chemical composition and antioxidant activity of essential oil from leaves and rhizomes of Curcuma angustifolia Roxb. Nat Prod Res 31 (18): 2188-2191 DOI: 10.1080/14786419.2017.1278600.

Kaisoon O, Siriamornpun S, Weerapreeyakul N, Meeso N. $2011 .$. Phenolic compounds and antioxidant activities of edible flowers from Thailand. J Funct Foods 3 (2): 88-89. DOI: 10.1016/j.jff.2011.03.002

KewScience. 2021. World checklist of selected plant families (WCSP). http://apps.kew.org/wcsp/

Khaleghi F, Yaacob WA, Din LB, Khalilzadeh MA. 2012. Volatile oil compositions of several parts of Etlingera fulgens from Malaysia. J $\begin{array}{llll}\text { Essent Oil-Bear Plants } 15 & \text { (2): 180-185. DOI: }\end{array}$ 10.1080/0972060x.2012.10644034.

Kubola J, Siriamornpun S, Meeso N. 2011. Phytochemicals, vitamin C and sugar content of Thai wild fruits. Food Chem 126 (3): 972-981. DOI : 10.1016/j.foodchem.2010.11.104.

Lu CL, Zhao HY, Jiang JG 2013. Evaluation of multi-activities of 14 edible species from Zingiberaceae. Intl J Food Sci 64 (1): 28-35. DOI: 10.3109/09637486.2012.694852.

Ivanović M, Makoter K, Islamčević Razboršek M. 2021. Comparative study of chemical composition and antioxidant activity of essential oils and crude extracts of four characteristic Zingiberaceae herbs. Plants 10 (3): 1-18 DOI: 10.3390/plants10030501.

Ma X, Wu H, Liu L, Yao Q, Wang S, Zhan R, Xing S, Zhou Y. 2011. Polyphenolic compounds and antioxidant properties in mango fruits . Sci Hortic 129 (1): 102-107 . DOI: 10.1016/j.scienta.2011.03.015.

Maneenoon K, Khuniad C, Teanuan Y, Saedan N, Prom-In S, Rukleng N, Kongpool W, Pinsook P, Wongwiwat W 2015. Ethnomedicinal plants used by traditional healers in Phatthalung Province, Peninsular Thailand. J Ethnobiol Ethnomed 11 (1): 1-20. DOI: 10.1186/s13002015-0031-5.

Raksakantong P, Siriamornpun S, Meeso N. 2012. Effect of drying methods on volatile compounds, fatty acids and antioxidant property of Thai kaffir lime (Citrus hystrix D.C.). Int J Food Sci Technol 47: 603-612. DOI: 10.1111/j.1365-2621.2011.02883.x.

Poonthananiwatkul B, Lim RH, Howard RL, Pibanpaknitee P, Williamson E. 2015. Traditional medicine use by cancer patients in Thailand. J Ethnopharmacol 168: 100-07. DOI: 10.1016/j.jep.2015.03.057.

Ratseewo J, Meeso N, Siriamornpun S. 2020. Changes in amino acids and bioactive compounds of pigmented rice as affected by far-infrared radiation and hot air drying. Food Chem 306: 1-11. DOI: 10.1016/j.foodchem.2019.125644.

Saensouk S, Saensouk, P, Pasorn P, Chantaranothai P. 2016. Diversity and uses of Zingiberaceae in Nam Nao National Park, Chaiyaphum and Phetchabun provinces, Thailand, with a new record for Thailand. Agric Nat Resour 50 (6): 445-453. DOI: 10.1016/j.anres.2016.08.002.

Saensouk P, Saensouk S. 2021. Diversity, traditional uses and conservation status of Zingiberaceae in Udorn Thani Province,

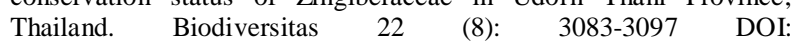
10.13057/biodiv/d220801.

Sembiring EN, Elya B, Sauriasari R. 2018. Phytochemical screening, total flavonoid and total phenolic content and antioxidant activity of 
different parts of Caesalpinia bonduc (L) Roxb. Phcog J 10 (1): 123 127. DOI: $10.5530 / \mathrm{pj} .2018 .1 .22$

Sepahpour S, Selamat J, Abdul Manap MY, Khatib A, Abdull Razis AF. 2018. Comparative analysis of chemical composition, antioxidant activity and quantitative characterization of some phenolic compounds in selected herbs and spices in different solvent extraction systems. Molecules 23 (2): 1-17 DOI: 10.3390/molecules23020402.

Shahid-Ud-Daula AFM, Kuyah MAA, Kamariah AS, Lim LBL, Ahmad N. 2019. Phytochemical and pharmacological evaluation of methanolic extracts of Etlingera fimbriobracteata (Zingiberaceae). S Afr J Bot 121: 45-53. DOI: 10.1016/j.sajb.2018.10.013.

Siriamornpun S, Kaewseejan N. 2017. Quality, bioactive compounds and antioxidant capacity of selected climacteric fruits with relation to their maturity. Sci Hortic 221: 33-42. DOI: 10.1016/j.scienta.2017.04.020.

Yang L, Wen KS, Ruan X, Zhao YX, Wei F, Wang Q. 2018. Response of plant secondary metabolites to environmental factors. Molecules 23 (4): 1-26. DOI: $10.3390 /$ molecules 23040762.

Yang D, Wang T, Long M, Li P. 2020. Quercetin: Its main pharmacological activity and potential application in clinical medicine. Oxid Med Cell Longev 2020:1-13. DOI: $10.1155 / 2020 / 8825387$

Yonekura-Sakakibara K, Higashi Y, Nakabayashi R. 2019. The origin and evolution of plant flavonoid metabolism. Front. Plant Sci. 10: 1-26. DOI: $10.3389 /$ fpls.2019.00943.

Yupparach P, Wongsuwan P, Phokham B, Sangnark S, Picheansoonthon C. 2019. Two new species of Cornukaempferia (Zingiberaceae) from Thailand .J Jap Bot 94 (2): 82-89.

Wang S, Yao J, Zhou B, Yang J, Chaudry MT, Wang M, Fenglin X, Yao L, Yin W. 2018. Bacteriostatic effect of quercetin as an antibiotic alternative in vivo and its antibacterial mechanism in vitro. J Food Prot 81 (1): 68-78. DOI: 10.4315/0362-028X.JFP-17-214.

Wanyo P, Kaewseejan N, Meeso N, Siriamornpun S. 2016. Bioactive compounds and antioxidant properties of different solvent extracts derived from Thai rice by-products. Appl Biol Chem 59 (3): 373-384. DOI: $10.1007 / \mathrm{s} 13765-016-0173-8$

Zargoosh Z, Ghavam M, Bacchetta G, Tavili A. 2019. Effects of ecological factors on the antioxidant potential and total phenol content of Scrophularia striata Boiss. Sci Rep 9 (1): 1-15. DOI: $10.1038 / \mathrm{s} 41598-019-52605-8$ 